\title{
DSPの誕生とその発展 (後編)
}

\section{技術}

の

原点

\section{The Advent of DSP and Its Growth in Human Society}

\section{西谷 隆夫 Takao NISHITANI}

今回の「技術の原点」は, DSP (Digital Signal Processor: 信 号処理プロセッサ)の発明者の一人として世界的に認知されて いる西谷隆夫先生によるDSP黎明期から現在までの発展につ いての後編です.（前編 : http://w2.gakkai-web.net/gakkai/ ieice/vol4.html) 後編では, DSPの市場が拡大するにつれ，非 技術的な競争が支配的になっていく現在までの状況，及び，今 後の発展について論じて頂いています，前編に引き続き，数々 のイノベーションについての, 興味深いエピソードをお楽しみ $\square$ 下さい。(編集委員会) $\square$

\section{（前編からつづく）}

\section{TI社の初代DSPの登場と NECの内 部事情}

まず，これから述べるT社の状況は，私の個人的な見方 であることをお断りしておく．先に述べたようにベル研究所 とNECのDSPに関する発表から2年遅れてTI社から彼らの DSPであるTMS32010 (17)の発表があった．その後の信 号処理に関する国際会議ICASSPの展示状況から判断すると 1983 年までは販売を開始していなかったようである.ただ し, TI社のブースではDSPの分厚いマニュアルを積極的に 配っており, TI社のDSPソフトウェアを開発するサードパー ティブースもTI社がサポートする形で並んでいた．これらの ブースも黒山の人だかりであった。 ちょうどIntel社が最初 の4ビットマイコンを宣伝していた時代をほうふつさせるよ うな光景である.マイクロコンピュータの開発者M. E. Hoff 氏が京都賞受賞の折, 「設計依頼会社のビジコンがIntelにマ イクロコンピュータの販売権を譲った時点では, こんなカリ キュレータ用の汎用チップを売り出すべきかどうか迷ってい た。しかし，TI社から来たセールスマネージャがIntel程度 の小さい会社 (当時は小さかった) がやるビジネスにはちょう どいいのだといって発売を決定した」と述べていたが, これ らの判断に基づく成功を見ると，つくづくTI社がセールス関 連で培った戦略的発売の英知に感心する。このあたりはベル 研究所やNEC と対照的である. ベル研究所は外販が目的で はないので宣伝しないのは当然として，NECがそれほど積

西谷隆夫 正員：フェロー 首都大学東京システムデザイン学部 Takao NISHITANI, Fellow (The Department of System Design, Tokyo Metropolitan University, Hino-shi, 191-0065 Japan)

Fundamentals Review Vol.2 No.1 pp. 09-21 2008年7月
極的な売出し方をしなかったのはそのような新製品の発売経 験がなかったことと, このような大規模な宣伝をすると当時 の米国法人であるNECマイクロコンピュータズの担当者が 対応しきれないと感じたのが本音ではないかと思う. 国際会 議でのTI社の動きを社内にレポートしても半導体部門の方々 からは「すごいね」という反応しか帰ってこなかった。

それではなぜNECはTI社のようにDSPに本腰を入れな かったかを，研究所にいた私の観測から述べてみたい，第 1 の要因は既に述べたように，独走期間中の宣伝不足などもあ りマーケットが爆発しなかったことである，第つには，もっ と大きな野望を半導体事業部は持っていたためだと思ってい る. 次期32ビットパソコン用マイクロプロセッサをNECが 一手に世界へ供給しようというプロジェクトである. 32 ビッ トプロセッサであるから, 当時のコンピュータ事業部とも競 合する. また, 当時絶好調だったPC98を扱っているパーソ ナルコンピュータ事業部も, IntelやMicrosoft と共同で事 業を進めていたため, 利害が相反する. 社内的には種々の問 題を抱えながら，世界中にマイクロプロセッサを供給する野 望を着実に進めたのがオリジナルマイクロプロセッサ V60 の開発プロジェクトである. このような戦略に至ったのは, Intel社のマイクロプロセッサと同じ命令セットで動作する チップは権利の侵害に当たるかどうかでIntel社と争った裁 判のためである. この裁判の和解以降, NECはIntel社製マ イクロコンピュータとの互換路線を捨てた. よってマイク ロコンピュータを大きな事業に発展させるには, パソコン用 マイクロプロセッサを取りにしきたいと考えるのは当然だっ た.また,「Chip-of-the-Year」作戦で作ったチップがすべ て良い評判をとったことなどから，「良いものを作れば良い 結果が得られる」という自信を持ったことも一因であると思 う. 当時の私はフロッピーディスクコントローラやDSP及 びグラフィックチップなどマイクロセッサとともに使う周辺 半導体分野の成功路線の延長で半導体事業部は業績を上げる ベきだと思っていた. しかし, 今になって過去を振り返ると 半導体事業部の決意のすごさに感服する. コンピュー夕関連 事業では過去のソフトウェア遺産を引き継ぐことが重要とさ れているが, 半導体事業部門の主張は,「これはマイク口コ ンピュータであり, 過去にはこだわらない」という姿勢を貫 き, オペレーティングシステムとして国産OSのB-トロンも 選択肢に入れた開発だったようである. 
結局，32ビットマイクロプロセッサの製品化が遅れたた めに、この野心はかなわなかった。「良いものでもタイミン グを逸すると成功しない」ということでもある，内部仕様書 や外部仕様書を決定するところで関連事業部門との調整など にも時間がとられたものと考える，この経験以降，半導体事 業部は世界に通用するMIPSア一キテクチャを積極的に取り 込んでマーケットの拡大を進めることになる，ただし，NEC 独自のVシリーズマイコンはその後も信号処理とRISCの融 合を図りつつ活動範囲を伸ばしていく戦略に变えたようであ る。現在は私の目から見ると初代DSPに似たV850が好調 である，信号処理機能を取り込んだRISCチップである，

事業を伸ばすという点では，DSPという新しい分野を活 用してマイクロプロセッサ関連を伸ばす方法を取るのも一法 である. しかしNECの半導体事業部はその方法は取らなかっ た. Intel社に対抗できるマイクロプロセッサのマーケットを 急いで獲得したかったということであろう．これに対して， T社も当時からマイクロプロセッサのビジネスを行っていた が，DSPをうまく活用してこの分野を獲得していったと考 える. そのために, アーキテクチャやC言語コンパイラなど, マイコンのユーザがDSPを受け入れやすくことを意識した 技術開発がされていたように思われる。

登場したTI社のDSPはアーキテクチャ的に目新しいもの ではなく, むしろ乗算器の入ったマイコンそのものであっ た. つまり, マイクロプロセッサの延長線上の製品としてと らえていた，確かにTI社のDSPにも16×16ビット乗算器 が組み込まれており，この乗算器と32ビットALUの組合せ で積を累算する機能がある，ただし，乗算器に対して同時に 乗数と被乗数の設定はできない，異なった係数を用いて新し いデータとの乗算を行ってフィルタリングするような構造を 取る場合には，乗算器を常時動作させることはできない，工 夫した点は乗算器とともに 16 ビットバレルシフタを付けた ことで, これもADPCM 標準化の演算精度に苦しめられた私 から見ると, シフ夕を2゙の乗算代わりに使うのだという意識 があったぐらいである，沉用マイコンのように内部メモリに プログラムとデータを格納できるが，細かい点はDSPの特 徵を持っており, 命令読出しとデータアクセスが同時にでき る.八ーバードアーキテクチャとして宣伝することになるが, それより先に現れていたDSPではマイクロプログラミング の機能として実現していた。. また，RISC とは異なり累算器 方式を採用しており，レジスタファイルはない，アーキテク チャ的な強化は少ないが，先行2社に比べて命令サイクルは $5 \mathrm{M} / \mathrm{s}$ と少し高く設定した，逆にこの速度を達成するために 外部から20MHzのクロックを供給することが必要で，これ を4相に分けて使っていたようである。1985年にはT社の DSPでADPCMを作った報告 ${ }^{(27)}$ が South Florida大学か らあったが，CCITT標準方式のような演算形式までは合わせ ていない、ボードに 18MHzのクロックと外部メモリやアナ ログインタフェース回路など種々の回路が必要であり, 図8 (前編を参照)で示したDSP化ADPCMボードの数倍の大き さになっている.TI社のDSPを動かすためにはかなりの力
作ボードを作る必要があったようである

TI社が一貫して述べているのは「C言語でプログラムでき る」ことである，当時のマイコンは C 言語コンパイラを用意 することが多く，一般ユーザは機械語やアセンブラ言語など に苦労するより, 高級言語のC言語を利用する風潮が高く なってきていた。 ここに演算能力の高いC 言語動作可能な DSPを導入することで，当時でも数多くいたマイコンのソ フトウェア技術者をDSPユーザに誘導する方法である。 般的なマイコンの場合は高級言語のコンパイラに任せて機 械語に翻訳させても，人手による細かい最適化アセンブラと の差は大幅には発生しない，C言語命令の現れてくる順番に シーケンシャルに翻訳するだけでよい，しかし，DSPには 並列に実行できる部分が多い，このため，性能を発揮するに は機械的な翻訳だけでは不十分で，アーキテクチャに依存し た命令実行順序の並び替えや，並列に実行できる複数の命令 をまとめて一つにするなどの工夫が必要である．このため, C 言語でプログラムを始めた技術者も苦労したのではないか と思うが，工夫することで普通のマイコンでは得られない高 機能タスクを実現できる．そこが技術者の腕の見せ所にもな る.

つまり，DSPのアーキテクチャが簡単であったため，C言 語でのパフォーマンスに満足できない場合は、コンパイル後 のアセンブラプログラムに対して技術者がアセンブラレベル のままで簡単に変更できる. 今考えれば,「クロックを多少 高くとり，簡単にプログラムするところまではコンパイラに 任せる，演算速度に満足できなければユーザ，もしくはサー ドパーティに工夫を任せる」というユーザ任せの戦略が多品 種少量生産向けの応用分野を育成した，この方法は同じマイ コンというLSIを大量に作ってLSI自体を安価にし、ソフト ウェアでユーザの必要とする機能をその上で実現するマイコ ン的アプローチであり, かつての上司が「DSPは多品種少量 生産向き」と言ったことと合致する. 多品種少量生産の分野 であるから個々のユーザのスキルに期待せずに，多くのユー ザを取り込む工夫が必要である. また，多品種少量生産向け の応用を実行するための華々しい宣伝活動をする必要があ る. TI社の高級言語CによるDSPは「乗算器付きマイコン を作ったので，信号処理に関しては余り慣れていない人でも プログラムできますよ」ということで，一般のマイコンソフ トウェアを開発していた人たちに抵抗なくDSPを受け入れ させた，これで応用分野も広がったと考えるのは，TI社が盛 んに宣伝していた分野がモ一夕制御であったからである。こ の分野は応用に応じて異なったソフトウェアを必要とするの であろう. 事実, その当時NECの半導体マーケットでTI社 のDSPに奪われたと報告があったのは，低価格の組込み用 マイクロプロセッサのみであったようだ。当時の乗算器を持 たない組込みマイコンを用いてソフトウェアによる乗算プロ グラムを動かす手間を考えれば，ちょっとした乗算が必要 であっても乗算器が内蔵されているDSPの方を使いたいと 思った技術者たちも多いのではないか，T社のDSPが高い 演算能力を持ち始めるのは 1980 年代後半から1990年代 
に入ってからのことになる．

余談ではあるが，なぜC 言語の効率がDSPでは悪いかを もう少し説明しておきたい。 パソコンなどで走るC言語から でも一応DSP用にコンパイルしたい。すすると, 結果もパソ コンで走らせたプログラムと同等のものが欲しい. PC用の C 言語プログラムでは演算はすべて倍長演算になっている. 初等関数を使う演算の場合はもっと悲惨で，二ュートン法な どの浮動小数点演算向きの近似計算法を使うことになること が多い，これを固定小数点のDSPでエミュレートするので は演算速度や効率は上がらない，固定小数点用のC言語に切 り換えると高速化できるものの, 内部メモリはキャッシュと して扱われ，配列などを定義すると外部メモリに置かれる. チップ内に閉じたコンパイルができればうれしいが, コンパ イラを顧客に配布するとなるとなかなかそうはいかない，結 局，想像以上にコンパイル結果は悪くなる．DSPの種類は 違うが，このあたりの問題を扱ったものとして文献 (28) が ある. アセンブラで書く場合の 100 倍も几長なプログラム になるとの報告である

ただし，最近のDSP用の固定小数点演算向けC言語コン パイラはかなり良くなってきている。度コンパイルしたら， オプティマイザと称する別プログラムでターゲットのDSP アーキテクチャに依存するコードに合わせ込む．ソフトウェ アパイプライニングとかループアンローリングと呼ばれる ループ処理演算のソフトウェア技法なども取り込むことで不 要コードを極力排除し，効率を上げている．最近のDSPの プログラム開発はC 言語を用いて開発をスタートさせること が多い。これは，DSPのアーキテクチャが複雑になってき たため, プログラムを最初からアセンブラを使って書く気が 起こらないことも原因である。コンパイラで予想以上に時間 のかかる部分は，最初のC言語プログラムに立ち返って，時 間のかかるC言語プログラムの部分を等価な C 言語プログラ ムで書き換えてコンパイルし直す。どうにも高速化の改良が できない場合はアセンブラによる修正を行っているようであ る.

\section{7. 浮動小数点DSP}

再びベル研究所とNECは第2世代とも言うべき浮動小数 点DSPで張り合うことになる. 先手を取ったのはベル研究 所で，1985年にnMOS技術による32ビットのDSP-32 (29)を,また，NECは1986年にCMOS技術による32ビッ トの $\mu \mathrm{PD} 77230^{(30)}$ を発表した.1986年の発表とい うのは私たちにとって重要な意味がある。この浮動小数点 DSPを1986年に日本で行われた信号処理に関する国際 会議ICASSP' 86 に動態展示したいというもくろみがあっ た。 世界中から2,000人ほどの研究者が東京の京王プラザ ホテルに集まるが，この機会に信号処理の研究者に「DSPの NEC」を宣伝したかったわけである.TI社のICASSPにお ける派手な宣伝に圧倒されていた私たちのささやかな抵抗で あった，準備は怠りなく，展示ブースを借り，動作中の例と

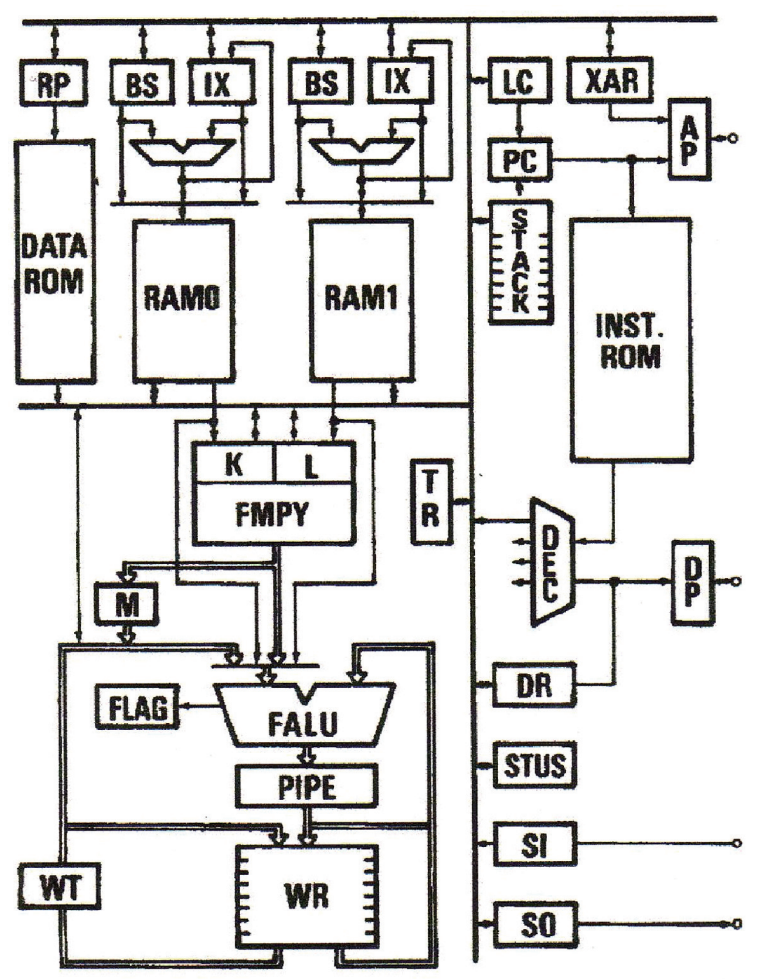

図11 浮動小数点DSP : $\mu$ PD77230

してMITのLim教授のアルゴリズムを彼の名前を付けてポス ター展示し，そのプログラムを浮動小数点DSPで走らせた 偶然来合わせたLim教授がそれに気づき, 見学していた皆さ んに彼のアルゴリズムの説明を開始するほどで, 計画以上の 成果であった，残念ながらブースは一つだけで，TI社が毎年 ICASSPで行っているような複数ブースでの展開ではなかっ た．偶然に訪れた人が見る程度の小さなブースである．

図 11 がNECの $\mu$ PD77230である.このプロセッサで は図12に示す2種類の浮動小数点形式を用意している。第 1 はメモリや乗算器で用いる32ビット浮動小数点形式であ り, 第2は55ビット浮動小数点形式で乗算結果と加算器に 用いる. 浮動小数点形式は数值 $\times$ を

$$
x=m \times 2^{e}
$$

という形式で表すことであり, 図 12の32ビット形式で 説明すると仮数部 (Mantissa: 式 (1)のm) は24ビット で表された 0.5 以上 1 未満の固定小数点で, また, 指数部

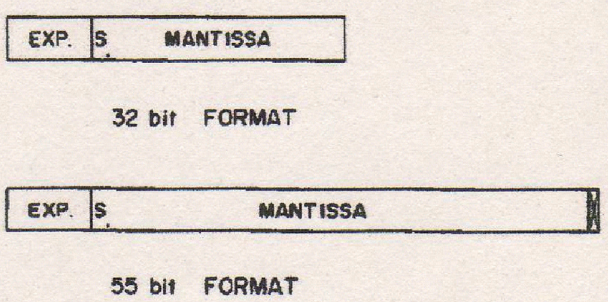

図12 浮動小数点フォーマット 32 ビット形式はメモリ格納 時 55 ビット形式は累算器形式 
(Exponent:式 ( 1 ）のe) は8ビットの2進数で表したもので ある. 図 11 の演算部において二つの浮動小数点乗算を考え ると，仮数の乗算結果は24 2424 ビットの乗算となり，48 ビットの積を得るが2ビット続く正負符号ビットを 1 ビッ トに節約すると47ビットになる。これに指数の8ビット 同士を加算して積の指数部8ビットを得る，つまり，先ほ どの47ビットの仮数部と指数部の 8 ビットを合わせた 55 ビットが浮動小数点の積の形式となり，これが図 12 の 55 ビット表現である，乗算器を使いやすくするためメモリは $\mathrm{RAMO} / 1$ と独立なメモリを二つ用いる構成にした。 メモリ アドレス生成回路は, FFTの処理に最適な構成にしている. また, ベル研究所とNECの浮動小数点DSPでは, 双方とも 浮動小数点形式として広範に用いられているIEEE規格には なっていない，IEEE規格は指数部オーバフローやアンダー フローに種々の例外処理を規定した演算形式である. DSP では演算回路を簡単にしてチップ当りの信号処理能力を重視 したいため, この辺りを簡略化した結果である，これで，命 令サイクルは2 倍弱に向上させることができた，第 1 世代で は250ナノ秒で 1 命令を実行していたが, 浮動小数点演算 DSPでは150ナノ秒に短縮した。

ベル研究所とNECが浮動小数点DSPの開発に踏み切った 理由は，多分双方ともADPCMにおける固定小数点DSPの プログラミングの煩わしさからユーザを開放したいと考えた ことにも由来しよう. 特にソフトウェアでデー夕变数を固定 小数点形式で扱う場合，小数点位置をどこに置くべきかは難 しい問題で, ダイナミックレンジ(数值の取り得る範囲) と演 算精度 (小数点以下の精度で量子化ノイズが決まる) を同時に 考慮しなければならない，これが単にプログラムの流れを制 御するだけでなく，出来上がったソフトウェアの性能を決定 するため, DSPのプログラミンングを一層難しくしている. 一般ユーザに使えるようにするには浮動小数点しかないと両 者とも考えたことが一因である

ただし，市場には第 1 世代DSPも健在である。また，後 述するが浮動小数点DSPをファミリー展開した固定小数点 DSPも出てきたため, 浮動小数点DSPのビジネスは苦しい ものになった，音声処理をターゲットにして誕生したDSP を32ビット浮動小数点化したのだが, 音声関連の研究で浮 動小数点DSPが大活躍したという報告は余り聞いていない. 組込み用途でも工夫して固定小数点でアプリケーションを 開発していたようだ. 固定小数点DSPを使えば浮動小数点 DSPより安価になるためである。つまり，16ビット固定小 数点DSPにおける倍精度演算の精度である 32 ビットもあ れば当時の音声処理には十分で, 浮動小数点演算のような広 いダイナミックレンジは必要なかったということである。

もう一つの原因は，浮動小数点DSPのシステム自体が大 規模になったことがある，この大規模なプロセッサを効率良 く動作させるには, いろいろのフラグを動的に, また, 適切 に設定しなければならない，このため，第 1 世代のDSP と 異なって, 浮動小数点プロセッサのアセンブラを効率良く書 けるようになるまでには相当量の学習が必要となる。学習し
てしまえば問題はないが, 余り使わないフラグ設定のタイミ ングなどはユーザズマニュアルでチェックすることも必要と なる.このことが原因で, 浮動小数点DSPは, 第 1 世代の DSPを知っている方々から, 図体は大きいが小回りが利か ないという意味で「戦艦大和」というニックネームで呼ばれて いたようだ

ダイナミックレンジや小数点位置に注意を払わなくてよい 今回の浮動小数点DSPの使いやすさを際立たせるため, 研 究所の私たちも高級言語を検討した，C言語の効率が悪いと のうわさも聞いていたので，専用言語を開発しようとした。 当時UCB (カリフォルニア大学バークレ一校)で研究を行っ ていたE. Lee教授のPtolemyシステムを手本にして,ブロッ ク図を描くとアセンブラプログラムができるようなブロック 図言語 ${ }^{(32)}$ に着手した。ちょうど, 現在のMathworks社の MATLAB, Simulink と同じようなものをイメージしていた. 前述したように浮動小数点SDPはに音声関係の信号処理に は余り使われなかったため, 画像や大量のスペクトル情報を 外部へ取り出す応用に進めようとした。 しかし，このような 応用には音声データ用のI/Oポートは不向きであった。内部 メモリと外部メモリのインタフェースに苦労が集中し, 高級 言語本体より, 入出力フォーマット変換で音をあげた．この ためこの研究は中断させるよりほかなかった. Simulinkを 見るたびに，当時の開発をもう一押しできなかったことが悔 やまれる．

第2世代DSPの開発にあたって，事業部は第 1 世代DSP に関する顧客ヒアリングを行っていた．その結果から，レー ダ等の計測信号処理には浮動小数点プロセッサが必要だとい う認識があった．この点は見事に的中した．浮動小数点演算 による利点が発揮されたのは，16ビット程度の固定小数点 演算では苦しかった 1024 点FFTなどであった. 固定小数 点でこれを行うと丸め雑音が大きくなりすぎてスペクトルを 用いた更なる処理が困難になる。つまり, 計測機器の分野で はFFTが必要な精度で確実にできる浮動小数点演算のDSP により，一世代前の音声処理での固定小数点DSP と同じ効 果であるソフトウェアの多芸性, 柔軟性が行き渡りだした。 この分野の人たちからは「有効に活用しましたよ」という声を 頂いている。ただし，音声分野に比べればマーケットは小さ いものであった.

第 1 世代DSPのときもそうであったが, 浮動小数点DSP でも複数の会社がこのような活動に呼応して開発や販売を開 始し出した. TI社は 1987年にTMS32030シリーズ(33)で この戦いに参戦したが, 今回も遅れ分を補うため, 20M命 令/秒 (乗算器と加算器があるので4OMFLOPS と宣伝して いる）亡高速命令サイクルを採用している点が他社と異なっ ている. 演算回路にパイプライン処理を活用したものである. また富士通もFDSP-4 ${ }^{(34)}$ という名称の浮動小数点DSPを 開発している.ただし, どの会社も最初の浮動小数点プロセッ サで大きなマーケットを築けたものはないのではないだろう か.

先にも触れた24ビット固定小数点DSPの計画は浮動小 


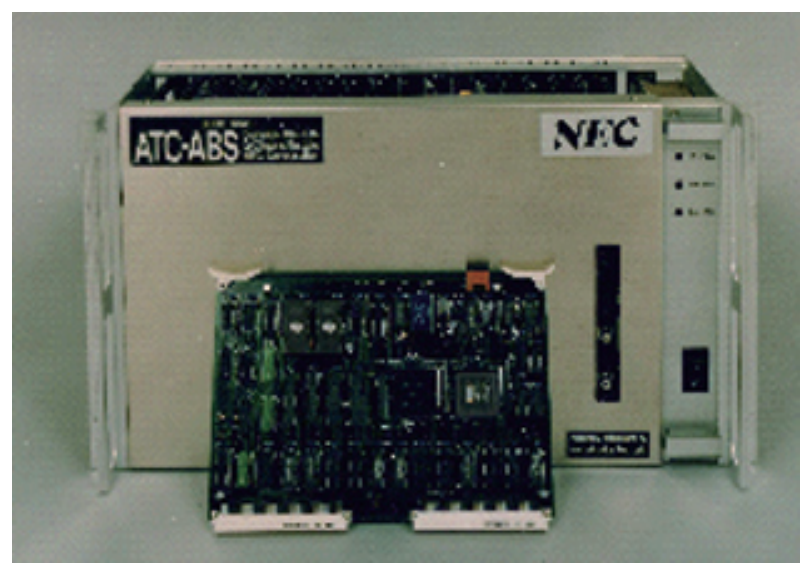

図13標準化のために持ち込んだコーデック． NECは変換部 を, 富士通とビクターが量子化器を担当するため大きなシステム としたが, 量子化部分は間に合わず, 結局私たちが作り上げた.

数点DSPの開発当初からあった. 先に浮動小数点形式は IEEE 標準ではないと説明したが，式（1）の指数部を取り除 くことで固定小数点プロセッサになることをねらった結果 でもある．内部メモリも24ビット幅である，個人的にはこ の24ビット固定小数点プロセッサが気に入っている.オー ディオ信号を扱う場合，DSPの演算語長が 16ビットという のは倍長演算ができたとしても苦しい，オーディオ信号のダ イナミックレンジ (最大の音の振幅と最小の音の振幅の比) は 120dB程度であるから20ビットは最低限必要で，演算の 丸め誤差 (10進法でいう四捨五入に起因する誤差) を考える と24ビットの演算精度は欲しい.

私たちはMPEGオーディオで24ビット固定小数点DSP を利用し，ADPCMの反省に立った標準化の良し点を味合わ せてもらった，良い点は「フィードフォワード制御」を採用し たので，DSPの演算精度にも比較的柔軟に対処できること である. 最終的にはMPEGも国際標準規格であるため, 専 用チップになってしまったが，DSPがそのままMPEGオー ディオのシステムチップとして貢献した時期や，DSPで実 現していたからこそ導けた高速アルゴリズムもある.この経 験をお話したい

当時の標準化では，ADPCMの場合と同様，提案システム を自力で開発し、コンテストに持ち込み，主観評価を行って 優劣をつけた，つまり，アルゴリズムを提案することは自分 たちのアルゴリズムを搭載した試作システムを開発すること である，当初 100 件を超えるアルゴリズムの提案があった が, 試作機を作る必要性から提案機関の数が激減した。最終 的には議長をつとめられた八ノーバ大学のMusmann教授の 指導によりアルゴリズムの似た四つのグループに分けられ， 各々のグループが 1 台の試作機を造ることになった，日本か ら直交变換方式で応募していたNEC, 富士通, ビクター, ソ 二ーは一つのグループにまとめられ，このグループでーつの 試作機を共同で作ることになった，先にも述べたようにDSP は試作システム作りには強力な力を発揮する。この特徵を有 効に使うべく，各社がある程度独立にもの作りが行えるよう にVMEボード上にDSPを搭載したものを作り，VMEボー
ド間を接続した図13のようなマルチDSPボードのコー デックを作ることになった，また，コ一デックを作るにあた り, 各社は自社提案の新規性を主張できる部分を担当するこ とになった. NECは变換部分をNECの $\mu \mathrm{PD77220,つま}$ り, 浮動小数点DSPの指数部を取り去った24ビットDSP で，また富士通とビクターは量子化部分を富士通のDSPで 作ることになった。 ソニーは当時ADPCMを用いたミニディ スク用コーデックを開発した直後であったため,「将来のミ ニディスク用コーデック」への参考に参加したいということ で, もの作りは行わないオブザーバ参加となった。

私たちの提案する直交变換アルゴリズムは信号の短時間定 常性に基づいてDCT变換 ${ }^{(35)}$ の符号化ブロック長を变える方 式 ${ }^{(36)}$ であった，この方式はブロック処理となる直交变換符 号化では避けられないプリエコーノイズの問題を軽減するも のである. 静かな状況から大きな音が急に出現する場合で, 出現時点がブロックの後半に起こると, 変換スペクトルは一 般に低域から広域まで広がったものになる。つまり，時間軸 では前半はゼ口, 後半に大きな振幅信号が起こるのに対して, 变換領域では全周波数に広がった信号になる。このためあら かじめ定められたビットレートで量子化すると, 広がった各 スペクトル成分すべてを対象にした荒い量子化になる，これ を時間軸に戻すとブロック全体に量子化ノイズが拡散する。 そうすると, 元々静かであった前半部分で量子化ノイズが顕 著になる。DCT直交变換方式で臨んだMPEGオーディオ標 準化の初期に私たちは独自の適応ブロックサイズ適応変換符 号化 (ATC-ABS) ${ }^{(36)}$ によりこのノイズを減らすことに成功 した. 時間軸上で半分程度が静かな区間が続く場合は变換ブ ロック長を半分にする. 前半部は周波数変換しても各スペク トルは小さい，後半部は依然として同じプリエコ一問題が残 るがノイズの顕著な区間は短くなる. つまり, 後半部分のプ

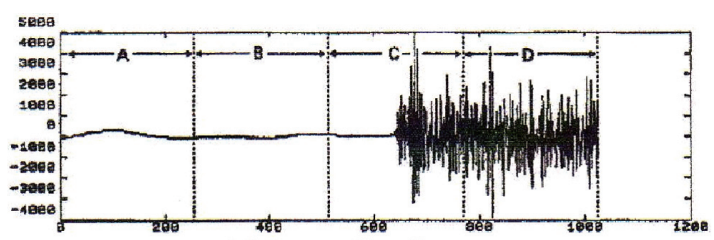

(a) Source Signal.

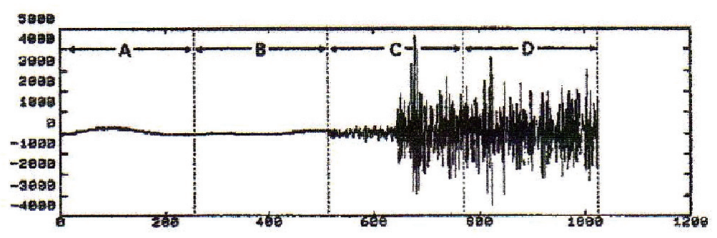

(b) Coded/Decoded Signal with a Block Size of 256.

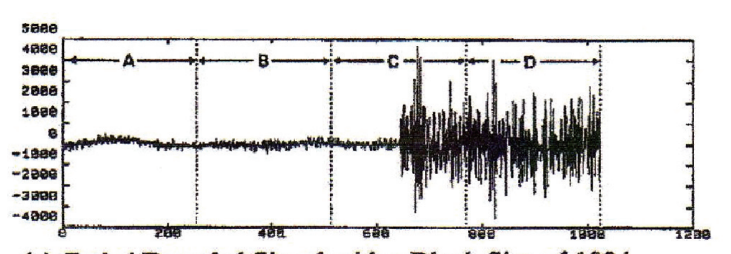

(c) Coded/Decoded Signal with a Block Size of 1024 .

図14 適応ブロックサイズATCの原理 
リエコーの区間が短くなる．人間の聴覚として直前の継続時 間の短く小さい音であるプリエコーは，直後の大きな音に隠 されてしまう傾向がある．これはバックワードマスキング効 果というもので，プリエコーを実質的に消すことができる. 図 14 はその効果を見いだしたときの図であり，(a) は元の 信号，(b)は短い変換ブロック長を用いた変換符号化の復号 信号，（c）は長いブロック長の場合の復号信号である。（c） は (b)に比べ, プリエコ一時間が長い.

実はこの標準化のグループ分けで，もう一つ異なった直交 変換方式を行っていたグループがある. ベル研究所と八イン リッヒ・ヘルツ・インスティテュート $(\mathrm{HHI})$ の連合部隊で, この部隊を率いていたのはこの記事の前編で述べた 1960 年代にADPCMの基礎を確立していたN.S.Jayant 博士で ある。彼らは直交変換にMDCT ${ }^{(37)}$ を採用していた。一般 に直交変換で符号化する場合はオーディオ信号をブロック化 する。すると，復号時にブロック間のつなぎ目に問題が発生 する，ブロック単位で直交変換を行った後に情報圧縮のため スペクトルを操作しており，次のブロックとの継ぎ目で不連 続が発生するのが原因である，不連続部分では音とび現象が 起こる．ブロック化操作するときにオーバラップさせて，そ の部分をウィンドウで滑らかに切り出す方法があるものの, オーバラップさせた分だけ圧縮率が下がるので圧縮符号化に は余り使いたくない.MDCTはこの問題を解決するもので， 信号のブロック化はオーバラップさせながらウィンドウを用 いて行うが, 変換に先立ち信号を折り返してブロック長を半 減させてから変換する，逆変換では半分の長さの信号を持つ ブロック長を元通りに折り返し直し，ウィンドウを再度乗じ て先のブロックと加算する．これでブロックの継ぎ目を滑ら かにできる。

MPEGオーディオの議長もこのMDCTは日本勢の使って いるDCT変換とは明らかに違うということを認識しており， 別グループになっていた。 しかし, 彼らもプリエコ一問題に は悩んでいた．私たちが適応ブロックサイズ方式を標準化会 議で提案すると, Jayant博士は日本勢に断りなく自分たち の方式に使ってきた，彼は良い物を作るのに躊躇しない人で もあったためである. このため, 私たちもべル研究所のグルー プに断りなく変換方式をMDCTに置き換えて検討を進めた. またしてもべル研究所とぶつかつたが，元々相互の欠点を補 完する技術であり, 同一方向に向かった研究を行っているた め, その後のMPEG-2 オーディオやMPEG-4オーディオに かけては切磋琢磨する同僚という立場になった

標準化作業に話を戻すと，以上の理由により期間中に急遽 DSPのプログラムを適応ブロックサイズ変換符号化に改造 し, 更に, DCT自体もMDCT ${ }^{(37)}$ 変換に修正して最終的な提 案アルゴリズム ${ }^{(38)} へ$ 変えていった。このようなことがで きたのは，私たちをはじめ，ベル研究所もソフトウェア制御 が可能なDSPのソフトウェアによる柔軟性を 100\%活用 した結果である。ここでは一例としてソフトウェアの挑戦に よって誕生した新しいアルゴリズムについて紹介したい。こ れは，DSPの内蔵メモリ不足に陥ったことによる。内部メ
モリが不足する状況に追い込まれると, アルゴリズムやソフ トウェアをやっている人たちは計算方法を工夫して同じ機能 を実現したくなるもので, この工夫の結果, 高速MDCTア ルゴリズム ${ }^{(39)}$ が導出できた. 高速アルゴリズムを用いると 無駄を捨て去ることができるため, メモリ使用量も削減で きる．このアルゴリズムのお陰で専用LSIを作るときにも内 部メモリを半減できた，多くのLSI会社がビデオデコーダよ りチップサイズの大きいオーディオチップを作っていたが NECのオーディオデコーダはコンパクトであった.

プリエコーを押さえ込んだ私たちの方式は適応ブロック サイズ変換符号化(ATC-ABS) と呼んでいるが, MP3や MPEG-2/4オーディオAAC (Advanced Audio Coding) にも採用され，また，ソ二ーのミニディスクコーデックも最 終的にはADPCM方式からATC-ABに変わった．これらの 特許で部下の2名には巨万の収入があると聞く. ATC-ABS などは私のアイデアと言ってもよい部分も多い，しかし，私 はこのときは研究の指揮を任されていたにもかかわらず, 特 許に名前を連ねていないため, 私の特許収入はない, 部下か らは何回か食事を御馳走になっただけである。ここでも優雅 な老後を逃してしまった

この標準以降は圧縮符号化の制御信号はすべてフィード フォワード制御，つまり，圧縮符号と独立に制御信号を送る 方式になった。このため, ADPCMのような演算順序や演算 精度まで定めた細かい仕様は必要なくなっている。 その効果 を味わえたのはMP3より早く標準が決まっていたMPEG-1 オーディオレイヤ2という方式に関してである. これも MPEG-1 の標準化で定まったもので，八ードウェアの規模 は小さいが良い音を出す，ちょうどこの標準が出来上がった ころ，ある会社からオーディオ伝送の端末を作るように依頼 があった. MPEGオーディオレイヤ2で送受を行うことは 決定したが，エンコーダはレイヤ2の符号化で活躍したフィ リップス社が担当する。私たちがデコーダを開発すると聞き つけたある海外の会社が,「フィリップス社のエンコーダは MUSICAMという方式で, デコーダを作るにあたって必要 となるビットストリームは我が社が一手に販売を引き受けて おり，買わなければシステムはつながらない」と言ってきた. 国際標準化ではMPEGオーディオ用のテストシーケンスが 定まっていたので,「もしつながらなければフィリップス社 がMPEGオーディオレイヤ2と違うものを作っことになり， 悪いのはフィリップス社」とはねつけた．理屈は私のいう通 りであるが, MUSICAM とはつながらないのではないかと 半信半疑であった。しかし, システムの発注会社で第 1 回目 の接続テストを行うと正常動作した.フフリップス社の符号 器にはMUSICAMという名前の横に小さく「MPEG-Audio Layer 2」と書かれていた，演算精度が異なっても十分な精 度であればつながることを製品として確認した第 1 歩であつ た.

更なる余談であるが, DSPでMPEG-1 オーディオレイヤ 己が出来上がったころは，パソコン用にPCMCIAカードの フラッシュメモリが売れ始めた時期でもあった，あるとき， 
私の指揮していたMPEGオーディオグループの一人が「オシ リ」を作りたいと言ってきた. よく聞くと「オーディオ・シ リコン」の略で, PCMCIAカードとDSPで作ったMPEG-1 オーディオチップを組み合わせ，コンパクトオーディオ端末 とするものである. 今で言う「iPod」と同じ機能である，名 前が格好悪いので「シリコン・オーディオ」と改名させ，作る ことに決定した．その後もう一人の部下がきょう体にデザイ ンを施し世界中に宣伝に回った。当然このシンプルな組合せ を特許にするように指示したが，今度は研究所の特許部門が 「単なるデコーダとそれに圧縮されたオーディオを組み合わ せただけの品のない特許」と判断して特許請求はさせてもら えなかった，確かに特許法には他の技術者でも容易に想像で きるものは発明ではないとあったようにも思う，それでも特 許として申請してみればよかったのではないだろうか．「シ リコン・オーディオ」という名称の商品登録だけは行った. 海外テレビの二ュースにまで取り上げられる反響があり，新 聞記事の広告にも載つた。そのときの読者アンケートとして 私が驚いたのは「モータがないのに何で音が出るの?」という 質問が多数あったことである

\section{8. その後のDSP一高速動作へ一}

1980年代後半はRISC プロセッサが登場して，それま でのマイクロプロセッサの動作速度が急激に上がってきた 時代でもある，また，通信の自由化が米国で推進された時 代でもあり, この流れに治ってベル研究所の役割も変化し, DSPなども外販できるようになった．ATT來下のWestern Electric 社からの販売である. ベル研究所はまたしてもこの 分野で先手を打ってきた。浮動小数点演算をあきらめ，高速 固定小数点演算に注力したDSP-16Aの登場である。アーキ テクチャはDSPらしくハードウェア効率の良い方式を取り ながらクロック周波数は30MHzにまで上げた.1988年あ たりに投入されたもので, 従来の3 倍程度の高速化であった. ベル研究所がこのようなDSPを開発した理由を推測すると, CELP(Code Excited Linear Prediction)音声符号化方式 ${ }^{(40)}$
があると思う.これはADPCMの国際標準が定まったあたり からベル研究所でAtal 博士が研究・開発を進めた方式で, 基 本的には音声合成技術を用いて次々に合成音を作り，これら を入力音声と比較して, 入力音声に近い合成音を作り出す音 声励起信号をパラメー夕化して送る方式である. 現在の携帯 電話の音声コ一デックとして使われているばかりでなく，IP 電話もこのCELP方式が多い.

CELPをもう少し詳しく解説する. 音声信号が入力される とLPC分析によりボコーダで使った喉や唇などの声道伝達 特性を抽出する. また, 前編で述べたボコーダの典型的な励 起パターンベクトルをベクトル量子化して複数個準備してお く．このベクトルを次々に声道伝達特性を持つフィル夕に入 カし, 最も入力音声信号に近い合成音声が出てきた励起信号 パターンのベクトル番号を相手側に送る．このためには，複 数個のベクトルパターンを持っているコードブックから次々 に音声合成を行って最適な入力音声を作るべクトルを探さな ければならない，演算量が増えるゆえんである。しかし，圧 縮効率は高く, 32kbit/sのADPCMに比べて 1/3から 1/8 に圧縮できる，携帯電話では基地局がサービスできる範囲を セルと呼ぶが, 同一セル内で許容できるユーザ数を増やすた めには一人当りのビットレートを削減する必要がある. ビッ トレートを低く抑えられるCELPは，携帯電話に最適であ る. ベル研究所もCELPは大きなマーケットに育つ携帯電話 の切り札と考えたものと思う. CELPを実現できるDSPに は, 演算精度より高速性が重要になる。よって, ベル研究所 のDSP-16Aは第 1 世代のDSP-20より演算精度の低い 16 ビットマシンとなったが, その分命令サイクルは $30 \mathrm{MHz}$ 高速化に力を入れたことになる．前編でDSP方法論を用い たADPCMのASIC化について述べたが，CELPにも高速な 回路をうまく使いこなすDSPが適している. また, フィー ドフォワード制御を行うことでフィードバック制御特有の演 算精度の問題を被ることもない, 更に, CELPは発展中のア ルゴリズムであり，変更が予想されたことから，DSPで実 現することがベストであったと思う

TI社が演算能力の高いチップを導入し出したのはこの辺

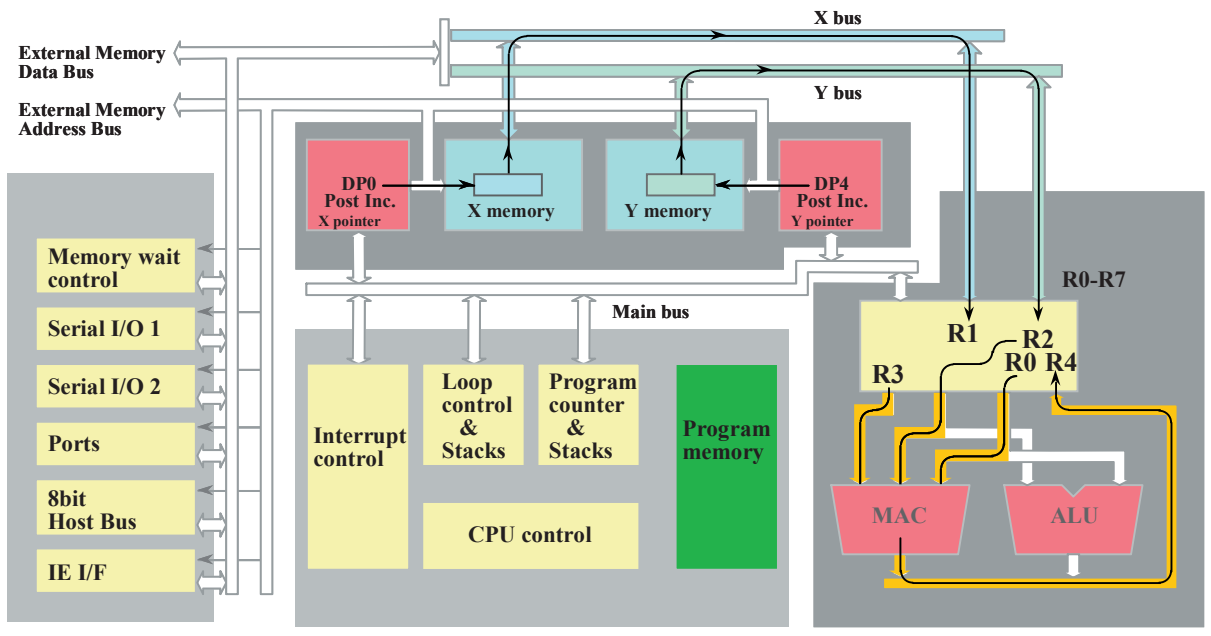

図15 NECの新しいDSP : SPX 
りからである. 私たちが浮動小数点プロセッサを発表した 1986 年当時では, 固定小数点DSPであるTMS320C25 $5^{(41)}$ を発表したが, 10M命令/秒であった．当時としては高速 な命令サイクルであったが，新風を吹き込むほどではない， しかし，TI社がDSPを製品の中核に置いてからは，クロッ ク速度の高速化と, 同一の演算器を複数持たせることによる 高機能化の両面でア一キテクチャ的にも優れたものを開発す るようになってきた．第2弾となる浮動小数点DSPである $\mathrm{C} 4 \mathrm{O}^{(42)}$ と特に携帯電話のアプリケーションチップのコアに なるC50/60 ${ }^{(43)}$ なたりからである

NECの高速化DSPは多少遅れ，1990年代に入ってから である。ただし，これ以降は私の活動は研究マネージメント が中心であり，NECの成果は主に部下に指示した結果であ る. 私たちにとってもDSPの高速化はCELPに対する強い 要望による。開発が遅れた分，RISCアプローチを徹底的に 取り入れる工夫を行った，この結果，RISC的なアプローチ として16ビットDSPとしては初めてレジスタファイルと ロードストア方式を導入した，メモリを直接アクセスするわ けではないので，手間のかかる外部メモリ参照から開放され た。つまり，演算はレジスタファイルからのデータのみに限 定し, メモリからのデータは一度レジスタファイルに取り込 んでから活用する。ロードストア方式にすることでプロセッ サ自体のパイプライン化が可能になった，高速性を発揮でき るゆえんである。この結果，16ビットDSPの分野でRISC との融合を本格的に行った初めてのDSP ${ }^{(44)}$ になった。ク ロック周波数は33MHzからスタートしたが, 次第に高速化 し，200MHzを超えるところまで引き上げて行った．

このDSPは「SPX」のニックネームで単体でも販売してい たが，次第にDSPコアとしてチップ内に作りつけられるこ とが多くなった，CELP方式はフィードフォワード形であっ たため, 国際標準化や3GPPの標準のCELP系の音声コ一 デックもDSPで実現できるようになってきたこともあって， DSPのコア化が一層進んだ。この辺りからDSPの性能はク ロック周波数ではなく単位周波数当りの消費電力で表すよう になった，これは，CMOS回路では電源電圧が一定の場合，

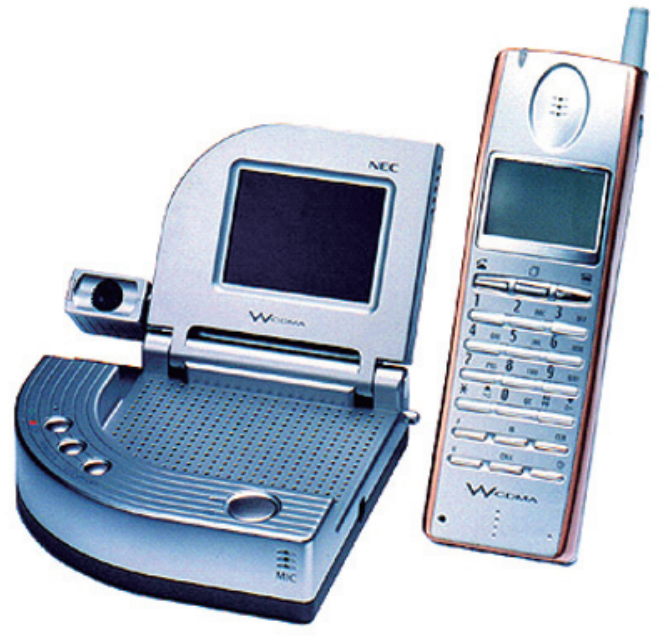

図16 3 G デモ機 (H.263搭載)
周波数と消費電力は比例関係にあり，低消費電力を実現する にはDSPへの供給クロック速度を落とせばよいからである

最初の携帯電話は音声電話のみの端末であったが, カメ ラが付き始めてからはDSPの重みが増してきた，撮つた写 真をJPEG圧縮しないと內部メモリがすぐにパンクする CELPの音声符号化に用意したDSPであるが，このDSP をJPEG圧縮にも使い，高速に処理したい，つまり音声コ一 デックとJPEGの二つの作業を行うようになってきた．更に DSPでの処理を拡大したのが第3世代の携帯電話である. 第 3世代の携帯電話はテレビ電話を実現するために64kbit/s の回線交換方式を取っている。ユーザの使えるビットレー トの上限がこれまでの携帯電話より拡大した，幸いNECの DSPはクロックを高く取れる，画面サイズも携帯電話では QSIF (Quarter SIF: NTSC画面の 1/16) と小さく, フレー ムレートも 15f/s (Frame per Second) 程度に設定するこ とも可能である。最も重い演算である動き補償機能を高速 FIRアルゴリズムで簡単化 ${ }^{(45)}$ することにより, ビットレー ト64kbit/sを用いることでSPXでも実現できた。図16に 示すのは3G携帯電話の実現に向けた国際展示会に出展した テレビ端末である。携帯電話による国際標準ITU-H.263を 用いたビデオ通信デモ機である．これによりますますDSP に対する期待が高まることとなる．ビデオだけでなくMPEG オーディオのDSP化もこのころに行っている. つまり， DSPのソフトウェアで携帯電話をマルチメディア端末とし て武装できることとなった

ちょうどこのころだったと思う。一連のDSPアーキテク チャに向いたアルゴリズム開発を「アーキテクチャ・ドリブ ン・アルゴリズム」と命名して力を入れようとした． 研究所 では年に 1 度, 各部の部長による中期計画や来年度の活動計 画を研究所のトップの方々に発表する機会がある，その場で DSPに人員を50名追加してほしい旨を訴えた。C言語の ような高級言語のアプローチに限界を感じていたので，いろ いろな標準に準拠するソフトウェアや高機能を演出できるマ ルチメディア関連のソフトウェアを準備して使いやすくする 作戦である.50名という数字はもう一つ研究部を欲しいと いうことと同じであるため却下されたが，それを聞いていた 別の部長は「何を馬鹿なことを!」と思ったそうである。しか し，1か月もたたないうちにTI社がDSPソフトウェア部門 を500名強化するという新聞発表があり, 反対に「西谷も肝 が小さい」という結論に変わったといわれている. 今振り返 ると, やはりねらった規模が小さすぎたのかという思いが強 い.

反対に丁1社は携帯電話マーケットに的を絞って着々と進 んでいたようである．特にDSP とRISCプロセッサである ARMプロセッサを単一チップに収め,一体化した標準チッ プOMAPの販売を積極的に推進した. このOMAPチップは, 携帯電話の変復調を行うチップと組み合わせることで携帯電 話のオーディオやビデオなどのマルチメディア機能を一手に 引き受けることになる，このため，これは携帯電話のアプリ ケーションチップと呼ばれている。米国の新聞記事でTI社を 


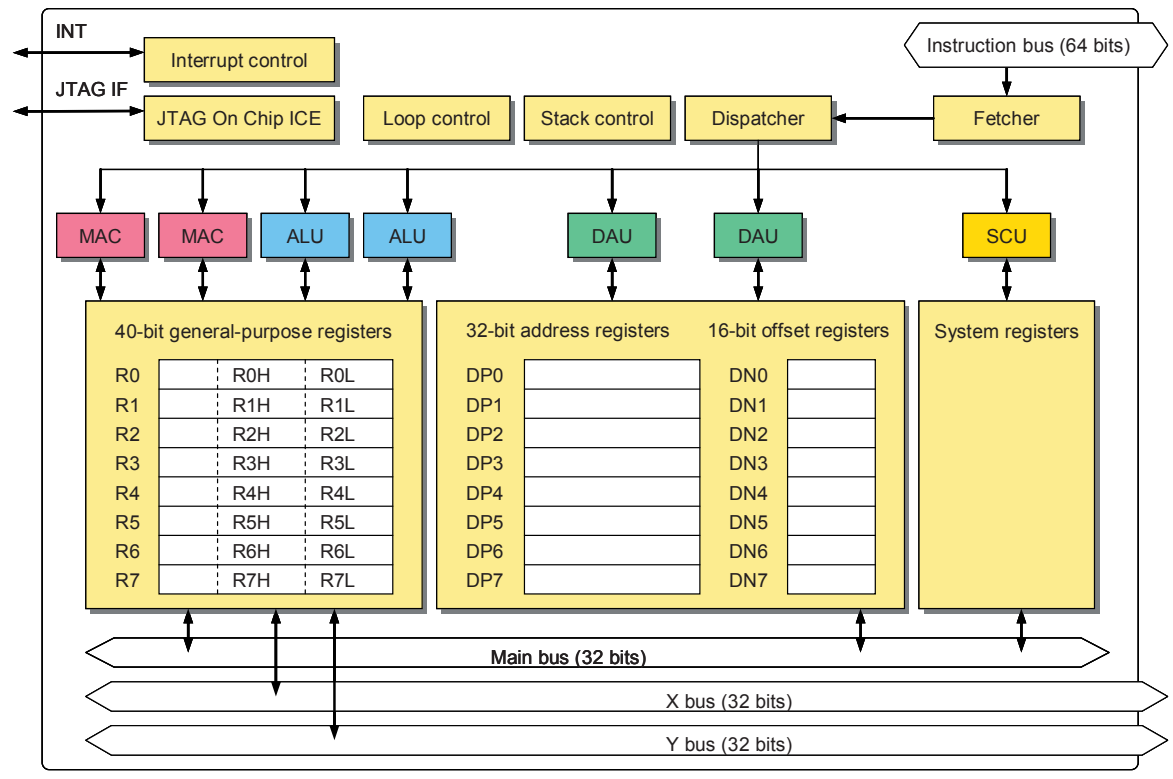

図17 NECの本格的な VLIW:SPX-K5

携帯電話部品会社と評した記事を見て，感心してしまったこ とを覚えている

ビデオやオーディオの本格的なDSPが始まったころから NECの次期DSPの計画が持ち上がった。本格的なVLIW (Very Long Instruction Word) 型の導入であったが, こ の計画はなかなか先に進まなかった．LSI事業部ではマイク ロプロセッサの開発に全力を集中しており，DSPへの投資 が余り行えなかった。このこともあり，事業部側の技術責任 者がプロセッサとしての完璧さを追求し，失敗は許されない 体制にしたためと考える。図 17 が開発したSPX-K5 ${ }^{(46)}$ ある。このブロック図にはメモリが付いていない，SPX-K5 はSOC (System On Chip) 用のコアとして設計されたた めであり，チップ化するときに周辺にメモリを積むことにな る。演算器はデー夕処理用に4個, アドレス計算用に2個, シーケンス制御用に 1 個の合計 7 個あり 呼ばれる制御部が，空いた演算器と待機中のマイク口命令の 状況から実行できるマイクロ命令を演算器に転送する。この DSPは 1 セグ放送のH.264デコードもこなせる能力をもつ ている.もっともVLIW型のDSPの開発自体はTI社の方が 早く、1990年代中期にはC60を発表している。また, TI 社ではビデオ符号化に専用エンジンを積んだDSPも開発し ている。一方, SPX-K5はソフトが中心のチップである。こ のように見ると，いつの間にか汎用性に対する方針がNEC とTI社で逆転したようにも思える。特殊なエンジンを包含し たC60を更に発展させたものが今後もC 言語でプログラム できるDSPなのかどうかはTI社の努力次第である.

最近の高速DSPに関して注意すべきことを一つ述べてお きたい，巨大マーケットが携帯電話であるため低消費電力が 大前提である。電源電圧はプロセスデザインの関係上 $1 \mathrm{~V}$ 程 度以下にできない，このため，1Vで動くフルCMOSゲー トで処理の高速化をすることになる，そのためには，先に述 ベたパイプライン処理を更に細かくする方法と, 演算回路を
複数個持たせるVLIWがある. どちらもプログラムの分岐や ジャンプで問題を発生する．分岐命令が直ちに実行できない ためである. パイプラインの場合でもVLIWの場合でもプロ グラムシーケンスは通常の順番に進むことを前提にして未来 の命令を先取りしている．プログラムシーケンス上でジャン プや分岐が起こり，現在の先取命令は不要と分かったら，新 しいプログラムシーケンスを準備する必要がある。このため に高速なプロセッサでは，分岐でとに12〜16サイクルが 無駄になる. 最近の信号処理では画素単位での処理も多く, その画素単位での処理には条件分岐が多い, 次の命令を準備 し直す無駄サイクルが馬鹿にならない，高速クロックを使っ ても利点が得られない状況にも陥る．低消費電力を考える必 要のある携帯電話のような応用では, クロック速度ばかりを 気にする時代は終わりつつあるという印象を強く持ってい る.

\section{9. 先手必勝のプログラム制御による MPEGビデオ用ASIC}

DSPの一連の開発の流れでは, 最終的にDSPがASICに 敗れることが多かった。しかし，標準化の考え方が，デコー ダのみを規定し，「エンコーダは製造メーカが自分の責任に おいてデコーダが動作できるコードを出せばよい」と言う立 場を取るようになってから変化してきている．H.261 テレ ビ会議システム規格からMPEG及びH.264に至るまでがこ の方針である．先に述べたMPEGオーディオもその流れの 中にあった，エンコーダに自由度を与えるということは，例 えASICといえどもプログラム制御を活用するメリットが生 きてくる，機能の改善が可能なことは技術的に顧客対応が しつかりできることを意味し，このことで更なる顧客を獲得 できる，すると，利益が上がるという理由で，他社に先立っ て先端プロセスにより同じ機能のチップを小さくでき, チッ 
プが小さいと歩留まりが向上して安価になる，よって，更に 顧客を集めることができる．以下ではDSPではないが，外 部に制御用のマイクロプロセッサを置くことによってベスト セラーとなったMPEG-2エンコーダチップの話をしたい. 単一チップを目指した当初のDSP とは対照的であるが, TI 社のDSPが人気を博した理由の一部が見えるような気がす る.ただし, マーケットは一般の人たちに向けた高級言語の 世界とは程遠く，SOCのプログラミングといってもよい世 界である

SPXが完成して程なくMPEG-2の標準化も行われた. MPEG-1 Audioに関しては先に述べたようにうまくいった が，ビデオは苦戦していた。 ヨーロッパ勢や米国ベンチャー が活発に動いていたためである。実は私たちもMPEG-1 ビデオのエンコーダ/デコーダに挑戦したが製品にならな かった. MPEG-2のデコーダでも状況は変わらなかった. MPEG-2デコーダはDVDやディジタル放送用のセットトッ プボックスなどに応用があるため大きな市場が期待できる. このターゲットを集中的に攻めてきた欧米が強い状況であつ た．この分野にはNECは事業部独自で挑戦し，健闘はして いるものの，外国勢の勢いを止めるところまでには至ってい ない.

一方, 私の方はMPEG-1 ビデオの失敗に対する復活 戦として, 半導体事業部とシステム LSI研究部の合同で, MPEG-2エンコーダプロジェクトを立ち上げることに執念 を然やしていた。一般に研究所トップの意向は，余りにも事 業部に密着した活動が続くと研究回帰へ,また, 余りにも研 究一本槍になると事業部支援への指示が出るものである．こ のときは研究への回帰に傾きつつあった時期であつたが，シ ステム LSI 研究部の当時の部長からも暖かい援助を頂けた. 結果として演算量のほとんどを消費する動き補償回路に柔軟 性を取り込んだシストリックアレーを構築できた。

この回路を含めたアーキテクチャの主体は半導体事業部か ら私の研究部に移ってもらった部下が中心となって行った. 種々のアーキテクチャの検討の結果, 外部にRISC プロセッ サを付け，このプロセッサが動作モ一ドを決定するアーキテ クチャ ${ }^{(47)}$ になった。このRISCプロセッサは単に動き補償 回路の静的なコントロールをするだけでなく，エンコーダ中 のバッファ制御をはじめ, 遅くても問題にならない高度な機 能の制御を行うのがその役割であった．外部に通常の組込み RISCを用いたが，いつの間にか制御ソフトウェアは許容メ モリ容量ぎりぎりまで使っていた。 それだけエンコーダに起 因する条件がいろいろあった。

この成果の論文「単一チップMPEG-2エンコーダ」を発表 した当初は「どこが単一チップだ」という批判も頂いた，外部 に沉用RISCプロセッサを持つためである．その後，多くの 会社が後に同じようなコンセプトでRISC プロセッサと動き 補償エンジンを同一チップに積んだ「本当の」単一チップエ ンコーダを発売した，当然，それらは制御用RISCプロセッ サをチップ内に収めたものであった。しかし，内部に作る RISCプロセッサは何らかの簡易化されたプロセッサであり，
使用可能なメモリサイズも小さい，また，特殊なプロセッサ にすると汎用RISC プロセッサ用の開発ツールが活用できな い.このような特殊なチップの上で, 制御対象パラメータが 多く，かつ，複雑な動きをするエンコーダを相手にするのだ から，このようなチップを作ってしまった他社の技術者はソ フトウェア開発で苦労の連続であったと思う.

このチップを事業部の方が売り込みに行くと，多くの装 置メ一カからは「自分の会社ではMPEG-2でビットレート xxMbit/sではこのような映像になる。このレベルが達成 できれば買う」という要求を出されることが多かった，汎用 RISCプロセッサを制御用に用いたといっても，ビデオを圧 縮するMPEG-2エンコーダは特殊なエンジンを多く含んだ システムで, 顧客ユーザが工夫して開発してくれるものでは なかった. 結局, MPEGアーキテクチャとMPEGの画質に 責任を持つ研究所がそのような対応ソフト開発までやる羽目 になった。しかし, そのお陰でチップの能力は日増しに向上 した. そうするとますます顧客が付く，製品対応の品質向上 ソフト開発を指示していた研究者には災難であったろう。た だし, この製品, EMMAシリーズは彼らのお陰で多くのビ デオディクスレコーダには複数個乗っているチップになっ た. ディスクに裏番組録画機能などがあれは, 複数チャネル 受信した映像を再びMPEG-2に圧縮してディスクに格納す ることになるため, 裏番組チャネル分のエンコーダが必要と なるからである．

このチップは現在でも世界でのマーケットシェアは一位だ と思う.これは外部に制御プロセッサを持ち出したことと, ソフトウェア開発まで研究所がかかわったことによる勝利で あった. TI社のDSPのように顧客がプログラムするのでは なく，事業部から見た研究所というサードパーティが性能の 良いプログラムを作る仕組みである。マーケットの大きい製 品分野では，顧客は機能だけを買うということである．ただ し，ここまで来ると研究者には研究に回帰してもらいたくな るのも事実であり，研究所トップの方々の苦悩が実感できる.

\section{0. 将来のDSPへの展望}

話は戻るが, 半導体事業部で浮動小数点DSPの開発が 一段落したころ, 研究所では並列DSPの開発を手掛けてい た. 音声の処理に端を発したDSPアーキテクチャではある が, ビデオ信号に対するDSPアーキテクチャもあるべきで はないかということである。確かに前述したK-5でもビデ オ処理は行えるものの, 一次元の音声から発したアーキテ クチャである.このビデオ処理向けのアーキテクチャを確 立したいという信念で始めたものがVSP (Video Signal Processor) (48), (49)である.この試作システムができる や，すぐにビジネスに結び付けたいという要望が伝送事業 部から起こった，当時はH.261 というテレビ会議システム の国際標準はまだ完成しておらず，CLI社 (Compression Lab. Inc.) の高速DCTベース符号化 ${ }^{(50)}$ と PictureTel 社 の Lapped Transform ${ }^{(51)}$ が争っており, NECはDPCM 


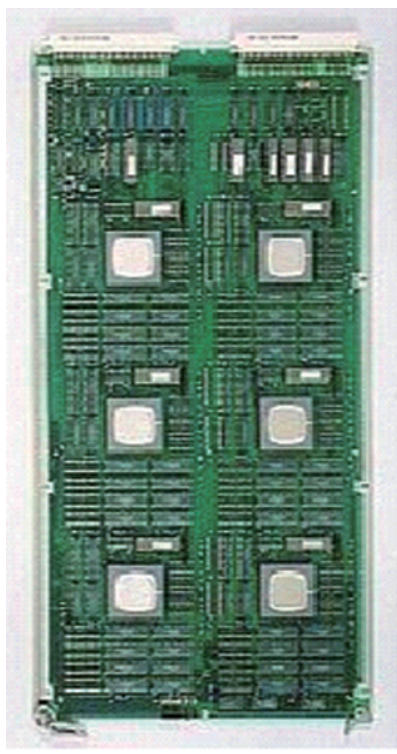

図18VISPボード

(Differential PCM) をベースに世界初の実用的な動き補償 技術である三段探索動き補償 ${ }^{(52)}$ を導入して対抗していた。 そこにPictureTel陣営がプロセッサ指向コーデックを持ち 込み, アルゴリズムは最新のものをいつでもお届けしますと いうサービスを始めた。一気にビデオ符号化もDSPの波に 飲まれそうな状況になった。私たちのVSPは画面分割によ る並列プロセッサで，画像の持つデータの並列性を 100\% 生かそうとしたものである.

VSPをベースにしたVSP用DSP ${ }^{(53)}$ はアーキテクチャ 設計を研究所が担当し，チップ開発は伝送通信事業部で行っ た．図18が開発した並列プロセッサボードであり，6個の VSP用DSPが整列している。最初の見積もりは，ビデオの 符号化は 18 個のDSPで実行するというものであったが，製 品に乗るときはアルゴリズムも膨れ上がり 36DSPを搭載 した。 つまり, 図18のボードが当初は3枚でよいという計 画であったが，実際にはその倍の6枚必要という結果になっ た．枚数増加の要因は, ソフトウェアによる実時間処理がで きるため, 部下たちが圧縮効率と画質を実時間で評価しなが ら，次々と新しいアイデアを導入していつたからである，当 時のビデオコーデックには標準規格がまだないため，ネット ワークで使われるより，本社と支社間というようなポイント 間伝送に使われていた程度である。このため, 100 台も同 じものが売れたら大ヒットという時代だった，この製品は VisuaLink-1000 という名称で数千台売れた，機能削減な どを行って3ODSP搭載というところまでシステムを縮小さ せたが，事業部の最初のもくろみと異なる大規模装置となっ て赤字出荷であったと思う．ただし，数千台売り尽くすころ にはH.261 というテレビ会議電話標準が出来上がってきた. このため, 大赤字だったこのシステムは標準化されたテレビ 会議システムの登場と共に次第に姿を消すことになった。や はり沉用DSPは専用LSIには負ける．ただし，このビデオ を処理するアーキテクチャは以下に述べるように現在までバ トンタッチされて継続出来ていると考えている
ビデオ処理におけるデー夕並列化の流れは, かつてデー タフロー型のプロセッサであるImPPを開発していたグルー プにも波及した，彼らはビデオ符号化ではなく認識を含めた ビジョンをねらうと宣言し, 自動車の自動走行認識などを目 標に, 図 19 に示すSIMD (Single Instruction, Multiple

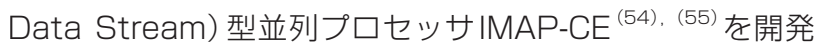
した. 128個の単位プロセッサ (PE: Processor Element) を 1 チップに搭載し，すべてのプロセッサを同一命令 (イン ストラクション) で動作させる.PEは 1 命令サイクルで4個 の独立な処理を実行する，DSPを並列に並べたようなもの である.PE間は隣接通信が可能である。このプロセッサは 高級言語としてC言語の拡張版を同時に開発していた。この ため実応用への対応が比較的簡単であった．最近ではある自 動車会社の最上位クラスの車に搭載されたと聞く. 自動車に 関する信号処理はちょうどテレビ会議システムの標準化以前 の状況と同じで, 次々と新しい認識技術や走行支援機能が出 来ている，つまり，DSPに打ってつけの分野である．また， この分野は通信方式と違って標準化アルゴリズムは必ずしも 要求されない，このため，今後のDSPの発展分野でもある と確信する

ただし, ある機能が特に重要という場合にはDSP対 ASIC で述べたように，DSPからASICへマーケット自体がシフト する可能性も高い，また第5節のDSP対ASICでも述べたよ うに，これからの汎用DSPは，FPGAやDSP開発ツールな どをべースとしてユーザが自分の応用分野に特化させたアー キテクチャを持つ特定分野向けDSP とも競争する. IMAPCEのようなマルチDSPを用いるのか，IPコアDSP と専用 エンジンやマイクロプロセッサと共存させたSOCを設計す るのかは, 応用分野の特性に依存する。 その応用分野で音声 オーディオ・ビデオに対する処理の多様性や新機能の追加が

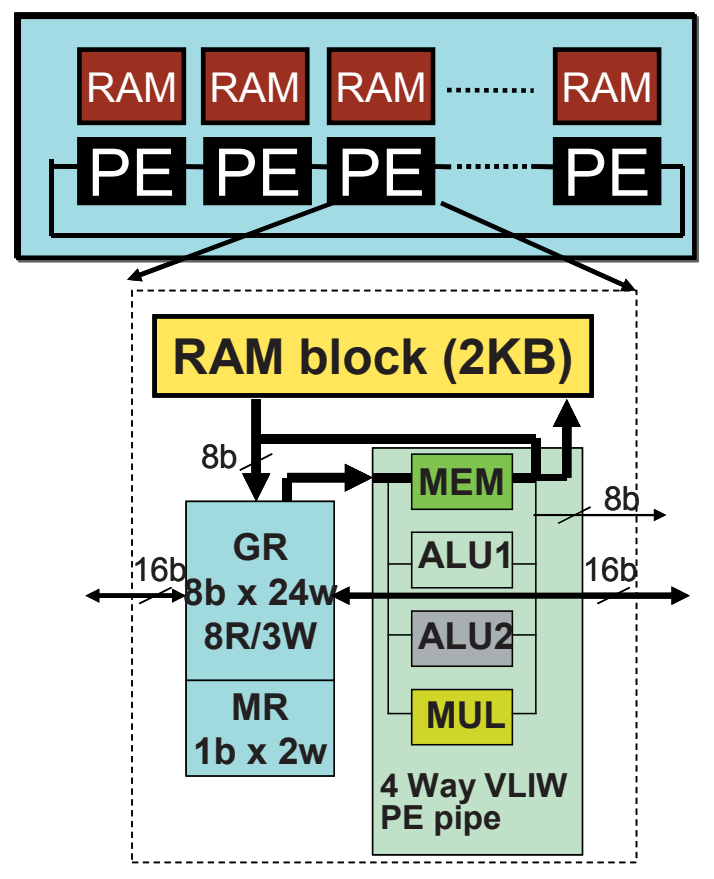

図19 IMAP-CEアーキテクチャ 
重要となる分野をねらうならばIMAP-CEを含む汎用DSPが 有利である。汎用DSPは八ードウェアの完成度の高さや開 発ツ一ルの整備状況が高いからである.SOC設計の場合で も，複数個のDSPをチップ内にあらかじめ準備しておくな ど，今後も汎用DSPはSOCの中核コアとして生き残ってゆ くと確信している.

\section{おわりに}

DSPの誕生する時代背景及び誕生の契機から最近のDSP までを，世界初のDSP開発者の視点で振り返った。 NEC と ベル研究所が切磋璬磨した時代から始め, 現在の携帯電話の アプリケーションチップとしてTI社が王座を占めている時 代を見てきたが，最終的にはビデオの高度信号処理の方向に 向かっており，まだまだ勝負は決まったわけではない。 ま た，本論ではDSPとASICの関係にも言及し，DSPの方法 論はASICにも活用されていること，しかし，ある特定機能 を実現したい場合にはDSPからASICへ移ることも述べた。 DSPが自由に活動できる環境は複数の機能がソフトウェア によって切り換えられる分野であり，その最も大きな分野が 携帯電話である. この分野は現在, TI社が王者となっており， この独走を許したのは確かにNECなどDSPに手を染めてい た会社の問題である。しか，内部にいたエンジニアとして は半導体事業部のDSPなどに気を散らすことができなかっ た大きな挑戦，世界の頂点を目指したマイクロプロセッサ供 給会社への脱皮を図った挑戦があったことも熟知しており文 句も言えない.

過去を振り返ると, 現在TI社が圧勝しているDSPでは， NEC も技術的には決して負けていないと確信を持っている。 ただし，C言語の開発ツールやマーケティングをはじめとす る顧客開拓戦略が弱かったと痛感する。この点では状況が変 わり得ると考えている，つまり，SOCの時代は一般ユーザ がソフトを開発するわけではない，このため，ビデオの符号 化以外の実時間ビジョン処理などでもう一波乱起こすことを NECに期待したい

今回，DSPの誕生から今までの流れを書くにあたり，い ろいろなことを振り返らせて頂いた。米国の日本バッシング に対抗する戦略として生まれたDSPであるが，DSPアーキ テクチャとその後に続く音声・オーディオ・ビデオの国際標 準化, また, 国際標準を実行するASICア一キテクチャ, 更に, 新しいDSPアーキテクチャに携われたことは技術者冥利に 尽きる，振り返って残念なのは，大きな特許料収入を 3 度も 失っていることであるが，大きな特許料の代わりに以下の大 きな夢を買ったと思っている．

私は学生時代にベル研究所というところはすごいところ だという意識を強く持っていた。 彼らの研究成果はBell Systems Technical Journalに載るが，これは研究成果の バイブルのようなものであって，IEEEなどの論文はその後 を追っていたという印象が強い，私の関連した分野はDSP から端を発し，その応用分野としての音声符号化，オーディ
オ符号化という領域であったが, 常にベル研究所の連中と切 磋琢磨する状況になった，少なくとも彼らとは対等に論じ 合ってきたと自負している。この自負は大企業の研究所に いて優秀な技術者とともに働けたからこそ得られたものであ る. NECの研究所で働くことが決まった入社のときに, ベ 儿研究所に一泡吹かせることができるような研究をしたいと 本気で望んでいたが，自分なりに何とかやってこられたのも 多くの技術者の力を借りたからにほかならない，一緒に研究 開発を進めてきた当時の新進気鋭の優秀な技術者たちに感謝 したい.

最後にこの記事を書くにあたり多大な御助言を頂いた NEC 研究所の宝珠山氏に感謝したい。

文献

（前編からの通し番号）

(27)R. Hangartner and V. .K. Jain, "32 kbs ADPCM transcoder using TI-320 DSP microcomputer," Proc. IEEE ICASSP' 85, 1985.

(28)S. Ono and Y. Kanayama, " Evaluation of a high Ivel language oriented program development system for high performance DSP DSSP!," Proc. IEEE ICASSP' 86, 1986

(29)W. P. Hays, R. N. Kershaw, L. E. Bays, J. R. Boddie, E. M. Fields, R. L. Frayman, C. J. Garen, J. H. James, J. Klinikowski, C. R. Miller, K. Mondal, H. S. Moscovitz, Y. Rotblum, W. A. Stocker, J. Tow, and L.V. Tran, "A 32 bit VLSI digital signal processor," IEEE J. Solid-State Circuits, vol. SC-20, no. 5, Oct. 1985.

(30) T. Nishitani, I. Kuroda, Y. Kawakami, H. Tanaka, and T. Nukiyama, "Advanced single-chip signal processor," Proc. IEEE ICASSP’ 86, 1986

(31) T. Temma, M. Iwashita, K. Matsumoto, H. Kurokawa, and T. Nukiyama, "Data flow processor chip for image processing," IEEE Trans. Electron Devices, vol. ED-32, no.9, 1985.

(32)।. Kuroda, T. Nishitani, T. Takeuchi, H. Koyama, J. Sunaga, and S. Matsukawa, "Blockdiagram programming system for 32 bit floating point signal processor." Proc. IEEE ICASSP' 87, 1987

(33)R. Simar Jr., T. Leigh, P. Koeppen, J. Leach, J. Potts, and D. Blalock, "A 40 MFLOPS digital signal processor: The first supercomputer on a chip," Proc. IEEE ICASSP' 87, 1987.

(34) H. Gambe, T. Ikezawa, N. Kobayashi, T. Tanabe, and S. Unagami, "A 32 bit floating-point signal processor FDSP-4 and its application to the communication systems," Proc. IEEE GLOBECOM' 87, 1987

(35) N. Ahmed, T. Natarajan, and K. R. Rao, "Discrete cosine transform," IEEE Trans. Comput., Jan. 1974.

(36) A. Sugiyama, F. Hazu, M. Iwadare, and T. Nishitani, "Adaptive transform coding with an adaptive block size (ATC-ABS)," Proc. IEEE ICASSP'90, pp. 1093-1096, 1990.

(37) J. P. Princen, A. W. Johnson, and A. B. Bradley, "Subband/transform coding using filter bank design based on time domain aliasing cancellation," ICASSP '87. 1987

(38) M. Iwadare, A. Sugiyama, F. Hazu, A. Hirano, and T. Nishitani, "A $128 \mathrm{kbps} \mathrm{HiFi} \mathrm{audio} \mathrm{codec} \mathrm{based} \mathrm{on}$ adaptive transform coding with adaptive block-size MDCT," IEEE J. Sel. Areas Commun., vol. 10, no. 1, pp. 138-144, 1992

(39)岩垂正宏，西谷隆夫，杉山昭彦，“MDCT方式に関する一 
検討と高速算法,”信学技報, DSP 90-13, pp.49-54 June 1990年6月.

(40) M. R. Schroeder and B. Atal, " Code-excited linear prediction (CELP) : High-quality speech at very low bit rate," Proc. IEEE ICASSP' 85, 1985.

(41)S. Abiko, M. Hashizume, Y. Matsushita, K. Shinozuka, and T. Takamizawa, "Architecture and applications of a 10Onsec CMOS VLSI digital signal processor," Proc. IEEE ICASSP' 86, 1986. (C25)

(42)R. Simar, Jr., P. Koeppen, J. Leach, S. Marshall, D. Francis, G. Mekras, J. Rosenstrauch, and S. Anderson, "Floating-point processors join forces in parallel processing architectures," IEEE J. Micro, Aug. 1992. (C40)

(43)R. Simar Jr., "DSP architectures, algorithms, and code-generation: Fission or fusion," Proc. IEEE 1997 Workshop on Signal Processing Systems, 1997. (C60)

(44)M. Yoshida, H. Ohtomo, and I. Kuroda, "A new generation 16-bvit general purpose programmable DSP and its video rate application," Proc. IEEE 1993 Workshop on VLSI Signal Processing, VI, 1993.

(45)Y. Naito and I. Kuroda, "H.263 mobile video codec based on a low power consumption digital signal processor," Proc. IEEE ICASSP' 98, 1998.

(46)T. Kumura, M. Ikekawa, M. Yoshida, and I. Kuroda, "VLIW DSP for mobile applications," IEEE Signal Process. Mag., July 2002.

(47) Y. Ooi, O. Ohnishi, Y. Yokoyama, Y. Katayama, M. Mizuno, M. Yamashina, H. Takano, N. Hayashi, and I. Tamitani, "An MPEG-2 encoder architecture based on a single-chip dedicated LSI with a control MPU," Proc. IEEE ICASSP' 97, 1997.

(48)T. Nishitani, I. Tamitani, H. Harasaki, M. Yamashina, and T. Enomoto, "Video signal processor configuration by multiprocessor approach," Proc. IEEE ICASSP' 86, 1986.

(49)I. Tamitani, H. Harasaki, T. Nishitani, Y. Endo, M. Yamashina, and T. Enomoto, "A real-time signal processor suitable for motion picture coding applications," IEEE Trans. Circuits Syst., vol.36, no.10, 1989.

(50)W.-H. Chen, H. Smith, and S. C. Fralick, "A fast computational algorithm for the discrete cosine transform," IEEE Trans. Commun., vol. COM-25, no.9, 1977.

(51) H. S. Malvar and D. H. Staelin, "The LOT: Transform coding without blocking effects," IEEE Trans. Acoust. Speech Signal Process., vol. 37, April 1989.

(52) T. Koga, A. Hirano, Y. lijima, and K. linuma, "Motion compensated adaptive intra-interframe predictive coding algorithm," Proc. IEEE ICASSP' 85, 1985.

(53) K. Kikuchi, Y. Nukada, Y. Aoki, T. Kanou, Y. Endo, and T. Nishitani, "A single chip 16-bit 25-ns video/image signal processor," IEEE J. Solid-State Circuits, vol.24, no.6, 1989.

(54)S. Kyo, T. Koga, S. Okazaki, and I. Kuroda, “A 51.2GOPS scalable video recognition processor for intelligent cruise control based on a linear array of 128 4-way VLIW processing elements," IEEE J. Solid-State Circuits, vol.38, 2003.

(55)S. Kyo, S.Okazaki, and T. Arai, "An integrated memory array processor for embedded image recognition systems," IEEE Trans. Comput., vol.56. no.5, 2007.

(平成20年2月12日受付 平成20年6月9日最終受付)

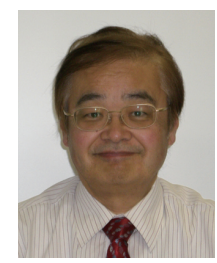

西谷隆夫 (正員 : フェロー)

昭 46 阪大.工・電子卒. 昭 48 同大学院修士課程 了. 同年日本電気 (株) 入社. 以来, ディジタル信号 処理ハードウェアと音声・ビデオ帯域圧縮の研究に従 事. 平 16 高知工科大・エ・システム・教授, 平 18 首 都大東京教授, 現在に至る. 博士 (工学). 昭 55 年度 本学会学術奨励賞, 平元科学技術庁長官賞, 平 9 ベル 研究所所長賞, 平13オーム技術賞各受賞. 著書「Digital Signal Processing for Multimedia Systems」など. IEEE Fellow. 